TECHNICAL SCIENCES AND TECHNOLOGIES

УДК 62-523.2

DOI: $10.25140 / 2411-5363-2019-3(17)-175-187$

Володимир Войтенко, Роман Сршов

\title{
МОДЕЛІ ЕЛЕМЕНТІВ СИСТЕМИ ЕЛЕКТРОПРИВОДІВ КВАДРОКОПТЕРІВ ТА АВТОНОМНИХ РОБОТІВ
}

Актуальність теми дослідження. Мінімізація енергоспоживання електроприводами безпілотного літального апарату (БПЛА) або робота дозволяє підвищити ступінь автономності (дальність, швидкість, або час дії).

Постановка проблеми. У середовищі для багатодоменного моделювання на рівні структурних схем Simulink®, яке інтегроване з MATLAB®, представлено декілька моделей електричних двигунів, автономних джерел живлення, а також елементів систем керування. Адекватний підбір блоків, які б дозволили успішно відтворити прототип реальної фізичної системи керування, потребує окремого вирімення.

Аналіз останніх досліджень і публікацій. Більшість публікаџій із моделювання в цій предметній галузі сфокусовано або на докладному описі роботи з MATLAB® та Simulink ${ }^{\circledR}$, або на моделюванні динаміки автономних апаратів та керуванні ними для забезпечення позииіонування у просторі.

Виділення недосліджених частин загальної проблеми. Питання оптимізаиії енергоспожсивання автономного об'єкта з кількома електроприводами залишається поза увагою.

Постановка завдання. Дослідження зосереджено на аналізі наявних Simulink-моделей електродвигунів, елементів жсивення та керування, які можна було б використати для подальшої розробки системи керування БПЛА або робота з автономним живленням.

Виклад основного матеріалу. Розглянуті особливості моделювання автономних апаратів, визначена динаміка окремого двигуна, сформульовано вимоги щоодо точності стабілізації швидкості обертання ротора, проаналізовані блоки Simulink для автономних апаратів, на основі яких запропонована комплексна модель електропривода для автономного апарата.

Висновки відповідно до статmі. Моделювання систем електроприводів автономних апаратів корисно як на початковій стадї проектування, так $і$ за наявності фізичного макета, оскільки суттево скорочує час та матеріальні ресурси, потрібні для розробки енергозаощадливої системи керування.

Ключові слова: модель електропривода; MATLAB; Simulink; безпілотний літальний апарат (БПЛА); автономний робот; енергоспоживання; безколекторний двигун постійного струму (БДПС).

Рис.: 3. Табл.:1. Бібл.: 20.

Актуальність теми дослідження. Безпілотні літальні апарати (БПЛА) та автономні роботи (АР) набувають дедалі більшого поширення в геодезії, геології, сільському господарстві, а також у спеціальних сферах [1]. Ці високотехнологічні вироби містять декілька керованих електроприводів, які живляться від єдиного автономного джерела (переважно акумулятора). Мінімізація споживаної електроприводами потужності дозволяє підвищити ступінь автономності пристрою (дальність, швидкість, або час дії).

Постановка проблеми. Дослідження методів енергоефективного керування пристроєм 3 автономним живленням доцільно розпочинати з етапу моделювання аби заощадити час та матеріальні ресурси. Комп'ютерне моделювання дозволяє дослідити поведінку об'єкта за умов різних завдань на керування, змін параметрів об'єкта, а також зовнішніх впливів та уточнити структуру та алгоритм роботи системи керування перед виготовленням вартісної фізичної моделі.

Найбільш поширеною програмою комп'ютерного моделювання мехатронних систем $\epsilon$ MATLAB ${ }^{\circledR}[2]$, що зумовлено наявністю відповідного інструментарію, документації та численних прикладів, а також можливістю генерації програмного коду для цифрових систем керування. Середовище для багатодоменного моделювання на рівні структурних схем Simulink ${ }^{\circledR}$ інтегроване з MATLAB ${ }^{\circledR}$ i містить графічний редактор, а також налаштовувані бібліотеки блоків динамічних систем.

У Simulink ${ }^{\circledR}$ представлено декілька моделей електричних двигунів, автономних джерел живлення, а також численні елементи систем керування. Адекватний підбір блоків, які б дозволили успішно відтворити прототип реальної фізичної системи керування, являє собою проблему, що потребує окремого вирішення.

Аналіз останніх досліджень і публікацій. Численні публікації присвячені опису принципів функціонування та початку роботи з MATLAB ${ }^{\circledR}$ та Simulink ${ }^{\circledR}$, наприклад, [3; 4]. Розпочинаючи з версії MATLAB® 2018 доступний приклад [5], в якому показано використання Simulink ${ }^{\circledR}$ для моделювання квадрокоптера на основі мінідронів. У цьому прикладі використовується підхід, визначений у [6] та адаптований до важкопідйом-

(C) Войтенко В. П., Сршов Р. Д., 2019 
TECHNICAL SCIENCES AND TECHNOLOGIES ного квадрокоптера у [7]. У [8] розроблена точна імітаційна модель квадрокоптера, яка була реалізована у Simulink та використана для оптимізації конструкції та налаштування параметрів керування.

Для аналізу навігації та навколишнього середовища аерокосмічних транспортних засобів і візуалізації їх польоту за допомогою стандартних приладів кабіни або тренажера польоту в MATLAB® передбачений набір інструментів Aerospace Toolbox. Aerospace Blockset ${ }^{\mathrm{TM}}$ забезпечує блоки Simulink ${ }^{\circledR}$ для моделювання та аналізу динаміки аерокосмічних апаратів, які далі можна візуалізувати у FlightGear Flight Simulator.

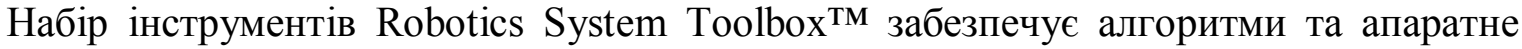
підключення для розробки автономних додатків робототехніки для повітряних і наземних транспортних засобів, маніпуляторів та гуманоїдних роботів. Наявні алгоритми дозволяють планувати траєкторію та шлях руху роботів, уникати перешкоди та оцінювати положення. Для роботів-маніпуляторів $є$ алгоритми зворотної кінематики, кінематичних обмежень та динаміки з використанням дерева жорсткого тіла.

Ця панель інструментів забезпечує інтерфейс між MATLAB ${ }$ i Simulink $®$ та операційною системою робота (Robot Operating System - ROS), що дозволяє тестувати та перевіряти додатки на роботах з підтримкою ROS i на симуляторах роботів, таких як Gazebo. Наявні приклади показують, як працювати з віртуальними роботами в Gazebo та 3 реальними роботами з підтримкою ROS.

Robotics System Toolbox підтримує генерацію коду C++, що дозволяє з моделі Simulink автоматично розгортати вузол ROS в мережі, за допомогою зовнішнього режиму Simulink, переглядаючи сигнали та змінюючи параметри під час роботи моделі.

Найбільш повна та актуальна інформація стосовно панелей інструментів MATLAB® міститься в [2], а також вбудована в довідкову систему цих програм.

Виділення недосліджених частин загальної проблеми. У зазначених вище та інших джерелах [9-14] йдеться, насамперед, про вирішення головного завдання системи керування БПЛА або робота, а саме, - реалізація руху за заданим законом. Проте питання оптимізації енергоспоживання автономного об'єкта 3 кількома електроприводами залишається поза увагою.

Постановка завдання. Метою статті $\epsilon$ аналіз наявних блоків Simulink та виявлення тих, які можна було б використати для подальшого моделювання та розробки системи керування БПЛА або робота з автономним живленням. До таких блоків можна віднести електродвигуни, елементи живлення та керування.

Особливості моделювання автономних апаратів. У [15] вперше висловлено ідею щодо підвищення тривалості польоту БПЛА за рахунок зниження перерегулювання i тривалості перехідних процесів у системах електроприводів апарата, що є особливо актуальним, враховуючи обмежену ємність акумуляторної батареї. Цю ідею можна поширити й на автономні роботи $з$ декількома електроприводами. Доцільно зазначити, що БПЛА називають «мініатюрними літаючими роботами» $[7 ; 8 ; 16]$, що підкреслює схожість підходів до аналізу та проектування таких автономних апаратів.

Як базову схему БПЛА з кількома електроприводами будемо розглядати квадрокоптер. Специфіка його роботи полягає в тому, що всі чотири електроприводи тягнучих гвинтів постійно перебувають у перехідному режимі, навіть якщо апарат перебуває в нерухомому стані (висінні). Адже сукупність дестабілізуючих факторів (потоки повітря, зміна маси БПЛА під час скидання навантаження, робота інших бортових систем) змушує регулятори, які вираховують поточні похибки кутів крену, тангажу та рискання перерозподіляти тягові зусилля між окремими електродвигунами.

У [10] запропонований стенд для вимірювання тяги, бокового зусилля й крутного моменту за допомогою тензодатчика. Також передбачено схему контролю батареї, яка вимірює напругу і струм двигуна. Дані записуються на комп'ютер за допомогою мікро- 
TECHNICAL SCIENCES AND TECHNOLOGIES

контролера для вимірювання аналогового сигналу з частотою дискретизації 400 Гц. Ці корисні ідеї можна використати під час розробки нової енергоефективної системи електроприводів автономного апарату, а от схеми контролю напруги і струмів двигунів доцільно зробити вбудованими, тобто невід'ємними складовими пристрою.

У БПЛА рекомендується застосовувати безколекторні двигуни постійного струму (БДПС), які допускають безпосереднє управління ротором без істотної втрати ефективності, тим самим усуваючи необхідність у редукторі, який був однією з причин вібрації в більш ранніх конструкціях [10]. Проводячи аналогії з роботами 3 автономним живленням, можна дійти до аналогічної рекомендації.

Тяга створюється кожним ротором за допомогою крутного моменту, що виробляє БДПС, причому динаміка кожного двигуна визначається

$$
\begin{gathered}
T_{e}=K_{i} i(t) ; \\
E=L d i(t) / d t+R_{a} i(t)+K_{e} \omega(t),
\end{gathered}
$$

де $T_{e}$ - крутний момент, створюваний двигуном; $E$ - напруга на двигуні; $i(t)$ - струм, що проходить через двигун; $\omega(t)$ - кутова швидкість обертання ротора. $K_{i}, R_{a}$ и $K_{e}-$ це константи, характерні для двигуна, причому $K_{i}$ - коефіцієнт крутного моменту; $L$ - індуктивність, а $R_{a}$ - загальний опір якоря двигуна; $K_{e}$ - постійна проти-ЕРС.

У підсумку в [10] виводиться, що тяга, створювана ротором, пропорційна квадрату напруги на двигуні. Кути крену, тангажу та рискання регулюються диференціальною тягою. Різниця тяги між протилежними двигунами забезпечує крутний момент крену й тангажу. Диференціальна тяга між двома парами двигунів, що обертаються у протилежних напрямках, забезпечує крутний момент рискання.

У [14] отримано модель динаміки квадрокоптера з використанням рівнянь Ньютона та Ейлера, запропоновані стратегії керування, а поведінка квадрокоптера спостерігається у віртуальній реальності за допомогою Simulink 3D Animation.

У [11] розроблено імітатор на основі Matlab-Simulink. За допомогою цього вдалося перевірити точність моделі й надійність алгоритмів керування. Крім того, 3D-графічний інтерфейс і вхід джойстика полегшили тестування системи. Також описано процес ідентифікації констант, зокрема, порівняння сталих, отриманих різними методами.

У підручнику з моделювання мехатронних систем у середовищі Matlab-Simulink [17] описані бібліотеки Simulink i Sim Power System для дослідження цих систем. Зазначено, що БДПС - це пристрої, в яких магнітоелектрична синхронна машина з трапецеїдальним розподілом магнітного поля в зазорі включена до замкнутої системи з використанням датчика положення ротора та напівпровідникового комутатора (НПК). У цьому пристрої на виході НПК i, відповідно, на обмотках синхронної машини, формується прямокутна напруга. Для отримання положення ротора в БДПС використовуються імпульсні датчики, а регулювання швидкості здійснюється за рахунок зміни напруги живлення НПК.

У [12] сформульовано проблему динаміки чотирьох двигунів, які використовуються у квадрокоптері для управління 6 ступенями свободи апарата. Стверджується, що передавальна функція першого порядку є достатньою для представлення динаміки ротора, що використовується в безпілотній системі чотирьохроторного типу.

$$
G(s)=\frac{K}{\tau s+1}
$$

У [9] представлено конструкцію телеуправління для мініатюрного безпілотного літального апарату. Як основа для проектування керування виведена проста динамічна нелінійна модель БПЛА, що діє для квазістаціонарних умов польоту. Розроблено контроль за положенням, який базується на інформації, знятій з інерціальної системи вимірювання. Для того щоб контролювати висоту БПЛА, розроблено адаптивний контролер, що уникає 
TECHNICAL SCIENCES AND TECHNOLOGIES

наземних впливів і грунтується на вимірюваннях, отриманих від ультразвукового датчика низької вартості. Для обчислення вертикальної швидкості використовується оцінка на основі запропонованої моделі. Також наведені експериментальні результати.

Стаття [13] є оглядом, який присвячений математичному моделюванню квадрокоптера та ідентифікації параметрів, які використовуються в представлених моделях. Параметри моделі (довжина плеча, загальна маса квадрокоптера, матриця інерції, коефіцієнти тертя, тяги та опору) можна отримати за допомогою експерименту, розрахунку або поєднання обох способів. Експериментальна ідентифікація виконавчого механізму зазвичай вимагає використання випробувального стенда.

Динамічні показники та робастність системи електроприводів мають вирішальне значення для продуктивності та надійності квадрокоптера. У невеликих квадрокоптерах здебільшого використовують одиночні силові польові транзистори (FET), модулюючи напругу привода на кожному двигуні з постійними магнітами [7]. У більш великих апаратах використовують БДПС з електронними регуляторами швидкості (electronic speed controllers - ESC). Для отримання максимальної продуктивності ESC мають бути належним чином сконструйовані. Найчастіше використовують ESC літальних апаратів для хобі, оскільки вони доступні та мають малу вагу. Однак у них є кілька недоліків.

Розробляючи професійний квадрокоптер, треба мати на увазі, що хобі-контролери часто мають вбудований обмежувач пікового струму, який протікає під час крокової зміни швидкості (до 100 А в приводі X-4 [7]). Відсутність обмеження пікового струму може призвести до просідання напруги шини живлення внаслідок внутрішнього опору акумуляторів, що призведе до скидання авіоніки. Сильні сплески можуть навіть призвести до пошкодження ланцюгів комутації ESC. Щоб уникнути цих проблем, швидкість роботи ESC змінюється повільно, збільшуючи час реакції та обмежуючи пропускну здатність привода. У випадку з Flyer X-4 хобі-контролери швидкості з обмеженим піковим струмом не встигали реагувати, щоб стабілізувати БПЛА.

Переважно код мікроконтролера для хобі ESC та внутрішні системи недоступні; у такому ESC не існує прямого вимірювання швидкості обертання ротора, що може потребувати додаткових датчиків. У [7] зазначено, що керування швидкістю за допомогою хобі-обладнання з високим коефіцієнтом підсилення замкненого контуру із частотою оновлення всього лише 50 Гц для Flyer X-4 неможливо. Доступні зараз програмовані хобі ESC можуть бути підключені до комп'ютера для тонкої настройки та пристосовані для керування швидкістю великого квадрокоптера. Однак у високопродуктивному квадрокоптері майже напевно треба використовувати електроприводи власної розробки, як у випадку з Ascending Technologies [1].

Щоб забезпечити автоматичну стабілізацію положення квадрокоптера, потрібна висока динаміка тяги, для чого мотори мають бути в змозі швидко розганяти ротори. На більшості відомих квадрокоптерів встановлюють легкі ротори, що дозволяє миттєво змінювати швидкість без додаткового контролю. Великі квадрокоптери мають більш важкі, високоінерційні ротори, а тому потрібно локальне керування для штучного покращення динаміки двигуна. На практиці продуктивність роботи замкнутої системи керування найбільш сильно обмежена максимальним миттєвим струмом батарей, i це домінує в розробці системи керування автономного апарата.

Динаміку швидкості БДПС можна представити однополюсною динамічною системою, для якої підходить пропорційне керування зі зворотним зв'язком [7]. Коефіцієнт підсилення системи керування, який можна реалізувати, обмежений максимальним піковим значенням, яке потрібне для парирування збурень і завдань, i, водночас, не викликає несправності в контролері. Метод розрахунку оптимізованої системи управління для привода з насиченим піковим значенням описаний у [18]. 
TECHNICAL SCIENCES AND TECHNOLOGIES

Якщо забезпечена достатня пропускна здатність, регулятору двигуна не потрібно підтримувати точну швидкість обертання ротора - система управління положенням всього БПЛА компенсує завдання моторів для стабільного польоту апарата. При цьому сили тяги як у вертикальному напрямі, так і паралельно Землі, пропорційні квадрату швидкості обертання роторів $[11 ; 16]$.

У [16] динаміка ротора загалом була ідентифікована та підтверджена за допомогою інструменту ідентифікації MATLAB. Зазначено, що функції передачі першого порядку достатньо для відтворення динаміки між заданою та реальною швидкістю пропелера.

Розробка симулятора OS4 [8] супроводжувалась послідовними вдосконаленнями динамічної моделі, схеми управління та апаратного забезпечення робота. Остання версія включає ідентифіковану динаміку виконавчого механізму, аеродинамічний блок, контролер уникнення перешкод та планувальник високого рівня для визначення точок маршруту. Кожен блок описується одним або декількома файлами Matlab i може бути легко включений в інші симулятори.

Нарешті, в [8; 16] наводиться вираз для входів моделі квадрокоптера у просторі станів $U_{1}, U_{2}, U_{3}, U_{4}$, які, фактично, є виходами контролера керування положенням:

$$
\left\{\begin{array}{c}
U_{1}=b\left(\Omega_{1}^{2}+\Omega_{2}^{2}+\Omega_{3}^{2}+\Omega_{4}^{2}\right) ; \\
U_{2}=b\left(-\Omega_{1}^{2}+\Omega_{4}^{2}\right) ; \\
U_{3}=b\left(\Omega_{1}^{2}-\Omega_{3}^{2}\right) ; \\
U_{4}=d\left(-\Omega_{1}^{2}+\Omega_{2}^{2}-\Omega_{3}^{2}+\Omega_{4}^{2}\right),
\end{array}\right.
$$

де $\Omega_{1}, \Omega_{2}, \Omega_{3}, \Omega_{4}$ - швидкості обертання роторів; $b$ - коефіцієнт вертикальної (thrust), а $d$ - коефіцієнт горизонтальної (drag) тяги. Змінна $U_{1}$ описує лінійний рух апарата, у той час як змінні $U_{2}, U_{3}, U_{4}$ характеризують повороти квадракоптера.

Таким чином, першочерговими блоками Simulink, які потребують аналізу, виходячи 3 мети дослідження, є:

- безколекторні двигуни постійного струму (БДПС);

- автономні джерела живлення;

- схеми контролю напруги і струмів двигунів;

- елементи керування БДПС.

Блоки Simulink для автономних апаратів. Під час створення складної моделі в середовищі MATLAB зазвичай використовується Simulink Library Browser, що є деревоподібною ієрархічною структурою, де розміщено моделі окремих елементів. Так, в Simulink ${ }^{\circledR}$ (Ver. 9.0 2017b) представлено декілька моделей електричних двигунів із постійними магнітами, а також відповідних регуляторів та інших компонентів.

Передусім розглянемо ті розділи Simulink $®$, де згадуються моделі безколекторних двигунів постійного струму (БДПС, Brushless DC Motor, BDCM), а також синхронних двигунів із постійними магнітами (СДПМ, Permanent magnet synchronous motor, PMSM).

Група Simscape / Power Systems / Specialized Technology / Fundamental Blocks / Machines містить модель Permanent Magnet Synchronous Machine, яку було вперше представлено у версії MATLAB R2006a. Компонент призначений для моделювання динаміки трифазної синхронної машини 3 постійним магнітом із синусоїдальною або трапецієподібною зворотною електрорушійною силою або динаміку п'ятифазної синхронної машини з постійним магнітом із синусоїдальною зворотною електрорушійною силою. Цей блок можна використовувати в режимі генератора або двигуна, що визначається знаком механічного крутного моменту Tm (позитивний для моторного режиму, негативний для генераторного). Електричні та механічні частини машини представлені моделлю другого порядку в просторі станів.

У синусоїдальній моделі створюваний постійними магнітами у статорі потік та електрорушійні сили синусоїдальні. Трапецієподібна модель припускає, що розподіл об- 
TECHNICAL SCIENCES AND TECHNOLOGIES моток і потік, що створюються постійними магнітами, виробляють три проти-ЕРС трапецеїдальної форми.

Трифазна трапецієподібна модель електричної системи грунтується на рівняннях, які виражаються у фазовій системі координат (система abc). Індуктивність фази приймається постійною і не змінюється залежно від положення ротора.

Механічна система описується такими рівняннями:

$$
\left\{\begin{array}{c}
\frac{d}{d t} \omega_{m}=\frac{1}{J}\left(T_{e}-T_{f}-F \omega_{m}-T_{m}\right) ; \\
\frac{d \theta}{d t}=\omega_{m},
\end{array}\right.
$$

де $\omega_{m}-$ кутова швидкість ротора (механічна швидкість);

$J$ - комбінована інерція ротора і навантаження;

$T_{e}$ - електричний момент, що продукує двигун;

$T_{f}$ - момент статичного тертя валу;

$F$ - коефіцієнт в'язкого тертя ротора та навантаження;

$T_{m}$ - механічний момент на валу;

$\theta$ - кутове положення ротора.

Гнучкість використання описаної моделі забезпечується великою кількістю налаштувань за допомогою трьох вкладок:

- Configuration Tab;

- Parameters Tab;

- Advanced Tab.

Вкладка Advanced Tab, зокрема, містить кнопку Compute from standard specifications. За iï допомогою можна увійти на сторінку power PMSynchronousMachineParams (рис. 1). На цій сторінці треба обрати вид протиEPC (Sinusoidal / Trapezoidal), міжфазовий опір та індуктивність, які легко виміряти безпосередньо на двигуні. Залежно від наявних відомостей про двигун або вимірювань можна вибрати базову константу: напруги (Voltage) або моменту (Torque), які прямо пов'язані одна 3 одною. Для цих та інших параметрів, які треба задати (момент інерції, коефіцієнт в'язкого тертя), індивідуально обираються одиниці вимірювання.

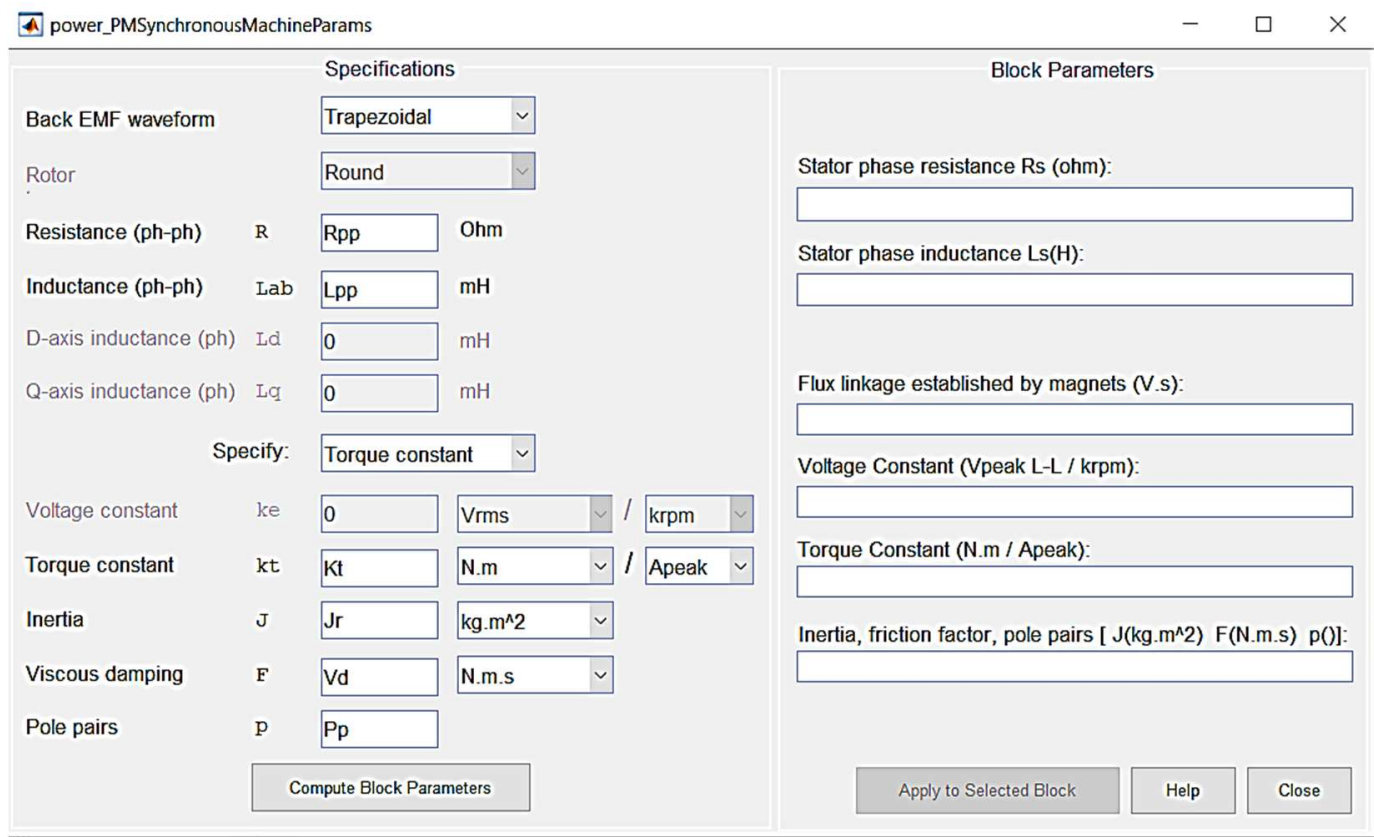

Puc. 1. Cторінка «Compute from standard specifications» блока Permanent Magnet Synchronous Machine 
TECHNICAL SCIENCES AND TECHNOLOGIES

Вхідним сигналом моделі є крутний момент, застосований до вала (Torque, Tm в н`м). А от вихідний сигнал моделі - швидкість машини - визначається інерцією машини J i різницею між застосованим механічним моментом Tm i електромагнітним моментом, який виробляє машина, і який представлений вихідним параметром Те.

Як приклад в таблиці наведено параметри БДПС DB59C024035-A. У графі «Ім'я» подане ім'я змінної у скриптовому файлі, який спрощує роботу з моделлю.

Таблиця

Параметри моделі БДПС DВ59С024035-А

\begin{tabular}{|c|c|c|c|}
\hline Ім'я & Значення & $\begin{array}{c}\text { Одиниця вимірю- } \\
\text { вання }\end{array}$ & Опис \\
\hline Rpp & 0.135 & $O M$ & Опір між фазами статора двигуна \\
\hline$R S$ & 0.0675 & $O_{M}$ & Опір статора двигуна \\
\hline Lpp & 0.2 & $M \Gamma$ & Індуктивність між фазами статора \\
\hline LS & 0.1 & ${ }_{\mu} \Gamma$ & Індуктивність статора двигуна \\
\hline Kt & 0.044 & $H \cdot M / A$ & Постійна моменту двигуна \\
\hline EMF & 3.7 & $B \cdot 1000 / x B^{-1}$ & Постійна проти-ЕРС двигуна \\
\hline Jr & $17.3 e-6$ & $\kappa 2 \cdot M^{2}$ & Інерція ротора \\
\hline $\mathrm{Vd}$ & $0.6 e-3$ & $H \cdot M \cdot c$ & В'язке тертя \\
\hline $\mathrm{Pp}$ & 6 & - & Кількість пар полюсів \\
\hline Sf & 0 & $H \cdot M$ & Момент сухого тертя \\
\hline IVPF & {$[\mathrm{Jr}, \mathrm{Vd}, \mathrm{Pp}, \mathrm{Sf}]$} & {$\left[\kappa 2 \cdot M^{2}, H \cdot M \cdot c,-, H \cdot M\right]$} & $\begin{array}{l}\text { Вектор значень: інерція, в’язке тертя, кіль- } \\
\text { кість полюсів, сухе тертя }\end{array}$ \\
\hline
\end{tabular}

Натискання на кнопки Compute Block Parameters та Apply to model дозволяє автоматично перерахувати решту параметрів моделі БДПС та розпочати процес симуляції. Таким чином вираховується опір та індуктивність статора. Слід принагідно зазначити, що MATLAB автоматично перераховує пікове значення постійної проти-ЕРС двигуна, у той час як у документації на БДПС часто дають значення цього коефіцієнта за середньоквадратичною напругою.

Приклад power_brushlessDCmotor ілюструє використання блока Permanent Magnet Synchronous Machine block.

У групі Simscape / Power Systems / Simscape Components / Machines / Permanent Magnet Rotor $\epsilon$ декілька моделей двигунів 3 постійними магнітами. Brushless DC Motor (безколекторний двигун постійного струму), представлений у MATLAB, розпочинаючи з версії R2013b, моделює синхронну машину 3 постійним магнітом, трифазним статором та обмотками зіркою. Модель має чотири варіанти завдання розподілу потоку постійного магніту як функції кута ротора. Для двох варіантів простої параметризації БДПС із трапецеподібною проти-ЕРС треба вказати або потокозчеплення, або проти-ЕРС. Інші два варіанти дають більш точні результати, використовуючи дані, наведені в документації на конкретний двигун. У цих випадках треба вказати або часткову похідну від потокозчеплення, або виміряну постійну протиЕРС для заданої швидкості ротора.

Ця модель більш деталізована порівняно з попередньою та передбачає задання великої кількості параметрів, а тому є найбільш гнучкою. Особливістю є можливість задання низки параметрів за допомогою таблиць. Деталізовані дані можна отримати на завершальній стадії розробки нової системи, коли за наявності фізичного макета, вдасться провести вимірювання та уточнити параметри двигуна. Моделювання, як і раніше, матимете сенс, оскільки допоможе спростити настроювання системи керування.

Декілька моделей електричних двигунів представлені в розділі Simulink $®$, який присвячений силовим агрегатам електромобілів. Так, у Powertrain Blockset / Propulsion / Electric Motors можна знайти Flux-Based PMSM (СДПМ на 
TECHNICAL SCIENCES AND TECHNOLOGIES основі потоку), Interior PMSM (внутрішній СДПМ), Mapped Motor (відображений двигун), Surface Mount PMSM (СДПМ для поверхневого монтажу). Зважаючи на специфіку застосування цих двигунів, досить відмінну від такої для автономних апаратів, розглядати їх тут не будемо.

Такожу групі Simscape / Electronics / Actuators \& Drivers / Rotational Actuators є ще один варіант моделі СДПМ - FEM-Parameterized PMSM із заданням параметрів за допомогою табличних даних магнітного потоку двигуна як функції струму і кута ротора. Цим способом сторонні пакети кінцевих елементів (Finite Element Magnetic, FEM) зазвичай експортують інформацію про потік. Через табличну форму потік може змінюватися нелінійним чином як від кута ротора, так і від струму. Тому цей блок можна використовувати як для моделювання СДПС із трапецеподібним профілем проти-ЕРС (тобто БДПС), так і зі звичайним СДПС. Ця модель могла б бути в нагоді під час розробки самого двигуна, отже, зважаючи на мету цього дослідження, використовувати ії не будемо.

Інші блоки Simulink для систем електроприводів. У групі Simscape / Power Systems / Specialized Technology / Electric Drives / AC Drives $\epsilon$, зокрема, модель Brushless DC Motor Drive (привод безконтактного двигуна постійного струму). Цей привод має замкнутий контур регулювання швидкості за допомогою струму статора, використовуючи датчики Холла. Контур регулювання швидкості задає опорний електромагнітний момент машини. Опорні фазові струми статора, які відповідають заданому моменту, виводяться на основі константи крутного моменту машини і сигналів датчика Холла. Потім опорні фазові струми використовуються для отримання необхідних сигналів затвора для інвертора через регулятор струму з гістерезисом.

Головною перевагою цього привода в порівнянні з керованими напругою ШІМінверторами БДПС є його плавна динамічна реакція. Цей привод забезпечує властивість обмеження струму/крутного моменту під час запуску та прискорення двигуна. Однак для належного функціонування привод потребує замкненого керування крутним моментом на основі сигналів струмів машини.

Блок Brushless DC Motor Drive використовує такі елементи бібліотеки Electric Drives / Fundamental Drive Blocks (Електричні приводи / Блоки фундаментальних приводів):

- Speed Controller AC (контролер швидкості);

- Current Controller (Brushless DC) (контролер струму БДПС);

- DC Bus (шина постійного струму);

- Three-Phase Inverter (трифазний інвертор).

Модель Current Controller (Brushless DC) являє собою гістерезисний контролер струму для використання з БДПС. Модель має два режими роботи, у яких інвертор може бути представленим детально або спрощено, за середнім значенням.

Блок PWM Generator (2-Level) (дворівневий ШІМ-генератор) генерує імпульси для перетворювачів на основі ШІМ, використовуючи дворівневу топологію. Блок може керувати комутаційними пристроями (FET, GTO або IGBT) трьох різних типів перетворювачів: однофазний напівмостовий (1 плече), однофазний повний міст (2 плеча) або трифазний міст (3 плеча). Опорний сигнал (вхід Uref), який також називають модулюючим, порівнюється із симетричним несучим сигналом трикутної форми. Коли опорний сигнал більший за несучий, для верхнього вентиля виробляється імпульс 3 рівнем «1», а для нижнього - «0».

Для управління однофазним повномостовим пристроєм можна вибрати однополярну або біполярну ШІМ-модуляцію. За допомогою однополярної модуляції кожне плече 
TECHNICAL SCIENCES AND TECHNOLOGIES

контролюється незалежно. Другий опорний сигнал внутрішньо генерується шляхом зсуву фази опорного сигналу на 180 градусів. Використання біполярної модуляції передбачає синфазну роботу (стан) нижнього комутаційного пристрою другого плеча та верхнього перемикача першого плеча, а також верхнього вентиля другого плеча та нижнього вентиля першого плеча. Уніполярна модуляція створює якіснішу форму змінного струму, але діапазон регулювання напруги малий.

Блок Battery з групи Electric Drives / Extra Sources pеалізує загальну динамічну модель, параметризовану для представлення найбільш популярних типів акумуляторних батарей. Параметри еквівалентної схеми можуть бути модифіковані для представлення конкретного типу батареї, виходячи з їі розрядних характеристик. Типова крива розряду складається з трьох ділянок.

Перша ділянка являє собою експоненціальне падіння напруги після зарядки акумулятора від повністю зарядженого стану до номінального значення. Друга ділянка характеризує заряд, який можна взяти з батареї, поки напруга не впаде нижче номінальної. Нарешті, третя ділянка представляє тотальний розряд акумулятора, коли напруга швидко спадає.

Модель дозволяє досліджувати вплив температури та старіння (внаслідок циклічності) на ємність літій-іонного акумулятора, для чого використовуються відповідні рівняння. Дуже важливою властивістю моделі з погляду цього дослідження є також можливість відображення динаміки зміни напруги (часу відгуку акумулятора) при ступеневій зміні струму навантаження. Крім того, модель дозволяє спиратися на детальні параметрів батареї, взяті з технічної документації (Data Sheets), а також отримані в результаті простих експериментів.

Група Electric Drives/Fundamental Drive Blocks, зокрема, містить блок Inverter (Three-Phase 3 версії MATLAB R2015b), призначений для моделювання стандартного трьохплечевого, дворівневого інвертора (детальний режим) або інвертора за середнім значенням напруги (усереднений режим). Середній режим має декілька варіантів залежно від типу двигуна змінного струму й дозволяє зменшити вимоги до продуктивності комп'ютера, який застосовується під час моделювання. У детальному режимі блок Inverter (Three-Phase) є екземпляром блоку універсального мосту (Universal Bridge), сконфігурованого у вигляді триланкового (трифазного) примусово-комутованого перетворювача. У цьому варіанті моделі можна обрати тип силового вентиля (GTO, MOSEET або IGBT).

Комплексна модель електропривода для автономного апарата. Наведена на рис. 2 модель базується на доопрацьованому прикладі Brushless DC Motor Fed by Six-Step Inverter (Examples > Simscape Power Systems > Specialized Technology > Machine Models power_brushless DCmotor.slx).

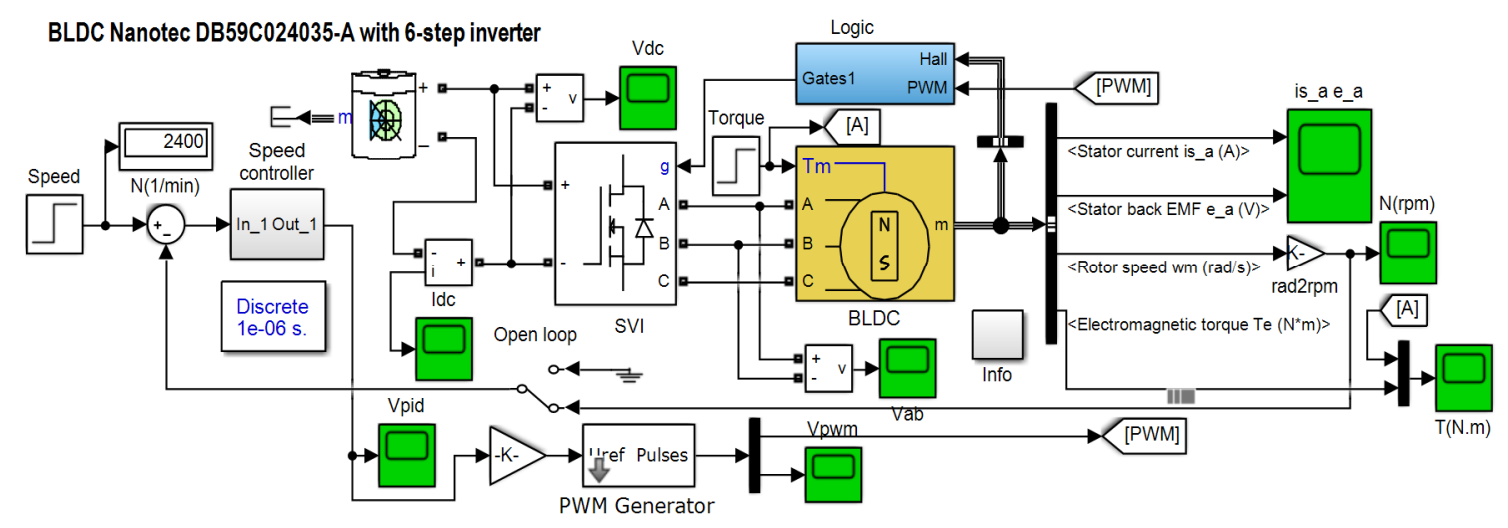

Рис. 2. Модель електропривода автономного апарата 
TECHNICAL SCIENCES AND TECHNOLOGIES

Шина постійного струму інвертора (SVI) підключена безпосередньо до акумуляторної батареї. Модель дозволяє працювати в режимі прямого ШІМ-регулювання одночасно всіма 6 вентилями АIH. Для керування трьома напругами фазних обмоток A, B, C статора двигуна (BLDC) використовується регулятор швидкості (Speed controller), вихідний сигнал якого впливає на коефіцієнт заповнення імпульсів, що генерує дискретний ШІМ-генератор (PWM Generator). Сигнали затворів MOSFET інвертора виробляються шляхом декодування сигналів датчиків Холла на двигуні та домішування до них сигналу PWM за допомогою блока Log i c.

Модель дозволяє досліджувати вільний хід двигуна. Для цього потрібно перемкнути тумблер у положення «Open loop» і встановити задану швидкість у значення холостого ходу $\left(\mathrm{SPEED}=\mathrm{NO}\right.$ LOAD_SPEED $=4500 x^{-1}$ відповідно до технічних параметрів двигуна). За допомогою блокf Torque можна ступенево змінити момент навантаження 3 нульового значення (коли рух двигуна зумовлений інерцією ротора та заданими значеннями в'язкого та сухого тертя) до номінального. Якщо виконуються всі зазначені умови, швидкість обертання ротора двигуна знижується до паспортного значення SPEED_RATED $=3500 x \boldsymbol{x}^{-1}$. Вибір двигуна та завдання параметрів моделі здійснюється у відповідному скриптовому файлі.

Експериментальні дослідження системи. На рис. 3 показаний результат моделювання перехідного процесу швидкості ротора електропривода автономного апарата із замкнутою системою керування. Параметри двигуна відповідають таблиці. У момент часу $t=0$ з блока Speed подається сигнал завдання швидкості $2000 x^{-1}$. Після перехідного процесу тривалістю близько 7 мс система відпрацьовує завдання холостого ходу з невеликою похибкою. У момент часу Torque_Step_time $=40$ мс блок Torque змінює значення момент навантаження 3 Torque_Initial_value $=0$ на Torque_Final_value $=0,6 H \cdot$. Стрибкоподібне збільшення навантаження змушує регулятор формувати відповідний керуючий вплив для ШІМ-генератора, що супроводжується підвищенням фазних струмів електродвигуна.

Усі інші сигнали системи можна спостерігати за допомогою відповідних блоків візуалізації.

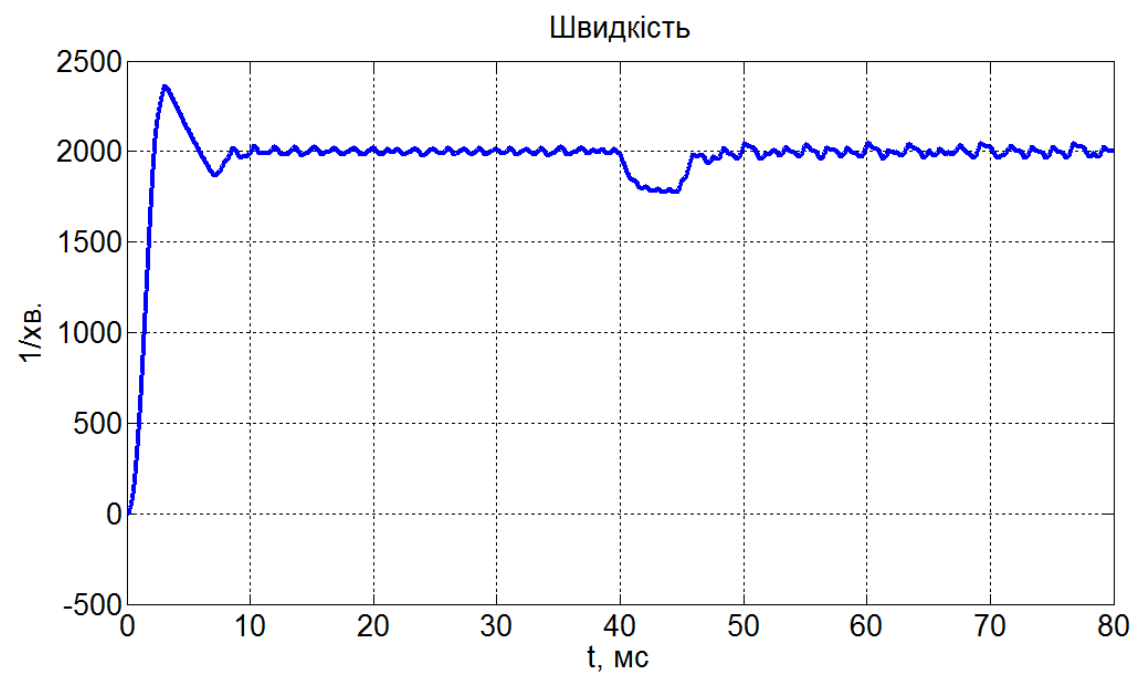

Рис. 3. Перехідний прочес швидкості ротора електропривода автономного апарата

Висновки відповідно до статті. Проведений аналіз розробок БПЛА та автономних роботів підтверджує актуальність застосування MATLAB® та Simulink ${ }^{\circledR}$ для досліджень цих автономних апаратів. При цьому: 
TECHNICAL SCIENCES AND TECHNOLOGIES

- схеми контролю напруги і струмів двигунів доцільно зробити вбудованими, тобто невід'ємними складовими самого автономного апарата;

- для високопродуктивних апаратів треба використовувати електроприводи власної розробки з якісною динамікою та можливістю доступу до всіх елементів;

- у розробці системи керування автономним апаратом домінує наявне обмеження миттєвого струму батарей, яке критично впливає на динаміку замкнутого контуру;

- якщо забезпечена достатня пропускна здатність, регулятору двигуна не потрібно підтримувати точну швидкість обертання ротора - система управління положенням всього БПЛА компенсує завдання окремих моторів для стабільного польоту апарата;

- тяга, створювана ротором, пропорційна квадрату напруги на двигуні, і в системах керування мультироторними БПЛА треба враховувати цей факт під час відпрацювання завдання та лінеаризації траєкторій руху;

- на стадії фізичного макетування системи електроприводів автономного апарату 3 метою спрощення настроювання системи керування доцільно використовувати більш точні моделі Simulink, що спираються на табличне завдання параметрів, які можна отримати за результатами випробувань.

Подальші дослідження доцільно зосередити в напрямку аналізу моделей силової частини елементів, а також розробки алгоритмів [19; 20] систем керування. Особливу увагу треба приділити дослідженню контуру струму, базовий варіант якого представлений блоком Current Controller (Brushless DC) (контролер струму БДПС).

\section{Список використаних джерел}

1. Ascending Technologies GmbH, 2019. URL: http://www.asctec.de/en.

2. Mathworks: Products and Services. URL: https://www.mathworks.com.

3. Дьяконов В. П. MATLAB. Полный самоучитель. Москва: ДМК Пресс, 2012. 768 с.

4. Zamboni L. Getting Started with Simulink. Birmingham: Packt Publishing, 2013. 115 p.

5. Quadcopter Project. URL: https://ww2.mathworks.cn/help/aeroblks/quadcopter-project.html?s tid $=$ srchtitle.

6. Prouty R. Helicopter Performance, Stability, and Control. Malabar: Krieger Pub., 2005. 731 p.

7. Ponds P., Mahony R., Corke P. Modelling and control of a large quadrotor robot. Control Engineering Practice. 2010.

8. Bouabdallah S. Design and control of quadrotors with application to autonomous flying. $\mathrm{PhD}$ dissertation, EPFL, 2007.

9. Guenard N. et al. Control laws for the tele operation of an unmanned aerial vehicle known as an x4-flyer. Proc. (IEEE) International Conference on Intelligent Robots (IROS'06). Beijing, China, 2006.

10. Hoffmann G., Huang H., Waslander S., Tomlin C. Quadrotor helicopter flight dynamics and control: Theory and experiment. AIAA Guidance, Navigation and Control Conference and Exhibit, 2007. $6461 \mathrm{p}$.

11. Bresciani T. Modelling, Identification and Control of a Quadrotor Helicopter. Master's thesis, Lund University, Sweden, 2008.

12. Kamran Joyo M., Ahmed S.F., Desa H., Tanveer M. H., Warsi F.A. Position Controller Design for Quad-rotor under Perturbed Condition. Wulfenia Jrnl., 2013. Vol. 20. No. 7. P. 178-189.

13. Chovancová A., Fico T., Chovanec L., Hubinský P. Mathematical Modelling and Parameter Identification of Quadrotor (a survey). Modelling of Mechanical and Mechatronic Systems MMaMS 2014. Procedia Engineering 96, 2014. P. 172-181.

14. Sabatino F. Quadrotor control: modeling, nonlinear control design, and simulation. Master's Degree Project. Stockholm, Sweden. KTH Electrical Engineering, June 2015.

15. Денисов Ю., Шаповалов О., Середа О., Куц С. Оптимізація енергодинамічних процесів у системі керування приводом стабілізації польоту безпілотного літального апарата. Технічні науки та технології. 2018. № 3 (13). С. 187-195.

16. Bouabdallah S., Siegwart R. Full Control of a Quadrotor. 2007 IEEE/RSJ International Conference on Intelligent Robots and Systems. P. 153-158. 
TECHNICAL SCIENCES AND TECHNOLOGIES

17. Герман-Галкин. С. Г. Matlab \& Simulink. Проектирование мехатронных систем на ПК. Санкт-Петербург: КОРОНА-Век, 2008. 368 с.

18. Ponds P., Mahony R., Corke P. Design of a static thruster for microair vehicle rotorcraft. Journal of Aerospace Engineering. 2009. № 22(1). P. 85-94.

19. Войтенко В. П. Адаптивное квазиоптимальное регулирование в преобразователях с нейросетевой моделью силовой части. Технічна електродинаміка. 2016. № 5. С. 26-28.

20. Войтенко В. П. Квазиоптимальные промышленные регуляторы с нейроидентификацией объекта управления: монография. Чернигов: Чернигов. гос. техн. ун-т, 2013. 261 с.

\section{References}

1. Ascending Technologies GmbH (2019). Retrieved from http://www.asctec.de/en.

2. Mathworks: Products and Services (2019). Retrieved from https://www.mathworks.com.

3. Diakonov, V. P. (2012). MATLAB. Polnyi samouchitel [Complete tutorial]. Moscow: DMK Press [in Russian].

4. Zamboni, L. (2013). Getting Started with Simulink. Birmingham: Packt Publishing.

5. Quadcopter Project (2019). Retrieved from https://ww2.mathworks.cn/help/aeroblks/quadcopterproject.html?s_tid=srchtitle.

6. Prouty, R. (2005). Helicopter Performance, Stability, and Control. Malabar: Krieger Pub.

7. Ponds, P., Mahony, R., Corke, P. (2010). Modelling and control of a large quadrotor robot. Control Engineering Practice.

8. Bouabdallah, S. (2007). Design and control of quadrotors with application to autonomous flying. PhD dissertation, EPFL.

9. Guenard, N. et al. (2006). Control laws for the tele operation of an unmanned aerial vehicle known as an $\mathrm{x}$ 4-flyer. Proc. (IEEE) International Conference on Intelligent Robots (IROS'06), Beijing, China.

10. Hoffmann, G., Huang, H., Waslander, S., Tomlin, C. (2007). Quadrotor helicopter flight dynamics and control: Theory and experiment. AIAA Guidance, Navigation and Control Conference and Exhibit.

11. Bresciani, T. (2008). Modelling, Identification and Control of a Quadrotor Helicopter. Master's thesis, Lund University, Sweden.

12. Kamran Joyo, M., Ahmed, S.F., Desa, H., Tanveer, M. H., Warsi, F.A. (2013). Position Controller Design for Quad-rotor under Perturbed Condition. Wulfenia Jrnl., 20, 7, 178-189.

13. Chovancová, A., Fico, T., Chovanec, L., Hubinský, P. (2014). Mathematical Modelling and Parameter Identification of Quadrotor (a survey). Modelling of Mechanical and Mechatronic Systems MMaMS 2014. - Procedia Engineering 96.

14. Sabatino, F. (2015). Quadrotor control: modeling, nonlinear control design, and simulation. Master's Degree Project. Stockholm, Sweden. KTH Electrical Engineering.

15. Denisov, Y., Shapovalov, O., Sereda, O., Kuts, Y. (2018). Optymizatsiya enerhodynamichnyh protsesiv u systemi keruvannia pryvodom stabilizatsii poliotu bezpilotnoho litalnoho aparata [Optimization of energy dynamical processes in the control system of the drive for stabilizing the flight of the unmanned aerial vehicle]. Technical sciences and technologies - Tekhnichni nauky ta tekhnolohii, 3 (13), 187-195 [in Ukrainian].

16. Bouabdallah, S., Siegwart, R. (2007). Full Control of a Quadrotor. IEEE/RSJ International Conference on Intelligent Robots and Systems.

17. German-Galkin, S. G. (2008). Matlab \& Simulink. Proektirovanie mehatronnyh system na PK [Designing mechatronic systems on a PC]. SPb.: Korona-Vek [in Russian].

18. Ponds P., Mahony R., Corke P. (2009). Design of a static thruster for microair vehicle rotorcraft. Journal of Aerospace Engineering, 22(1), 85-94.

19. Voytenko, V. P. (2016). Adaptivnoye kvasioptimalnoe regulirovanie v preobrazovateliah s neyrosetevoy nodeliyu silovoy chasti [Adaptive quasi-optimal regulation in converters with a neural network model of the power unit]. Tehnichna elektrodynamika - Technical electrodynamics, 5, 26-28 [in Russian].

20. Voytenko, V. P. (2013). Kvasioptimalnye promyshlennye reguliatory s neyroidentifikatsiey ob'ekta upravleniya [Quasi-optimal industrial controllers with neuro-identification of the plant]. Chernigov: ChDTU [in Russian]. 
TECHNICAL SCIENCES AND TECHNOLOGIES

UDC 004.9

\section{Volodymyr Voytenko, Roman Yershov}

\section{MODELS OF ELEMENTS OF THE ELECTRIC DRIVE SYSTEM OF THE QUADROCOPTERS AND AUTONOMOUS ROBOTS}

Urgency of the research. Minimizing the power consumption of unmanned aerial vehicles (UAVs) or robots can increase the degree of autonomy (range, speed, or operation time).

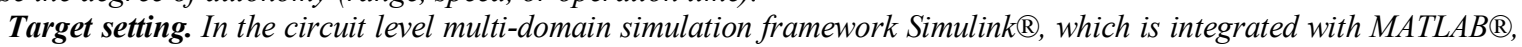
several models of electric motors, standalone power supplies and control elements are presented. Adequate selection of blocks to successfully reproduce a prototype of a real physical control system requires a separate solution.

Actual scientific researches and issues analysis. Most publications on modeling in this subject area are either focused

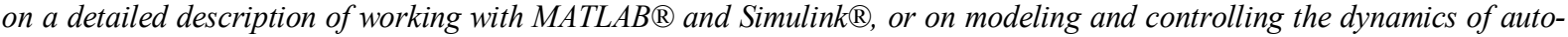
nomous vehicles to provide positioning in space.

Uninvestigated parts of general matters defining. The issue of optimizing the power consumption of a standalone multidrive object remains unaddressed.

The research objective. The study focuses on the analysis of existing Simulink models of motors, batteries and controls that could be used to further develop a control system for UAV or robot with standalone power.

The statement of basic materials. Features of modeling of autonomous devices are considered, dynamics of a separate motor is determined, requirements for accuracy of stabilization of rotor speed are formulated, Simulink blocks for autonomous devices are analyzed, on the basis of which a complex model of electric drive for autonomous apparatus is proposed.

Conclusions. Modeling the drive systems of autonomous vehicles is useful both at the initial design stage and in the presence of a physical layout, since it significantly reduces the time and material resources required to develop an energyefficient control system.

Keywords: model of electric drive; MATLAB; Simulink; Unmanned Aerial Vehicle (UAV); autonomous robot; power consumption; brushless DC-motor (BLDC).

Fig.: 3. Table: 1. References: 20.

Войтенко Володимир Павлович - кандидат технічних наук, доцент, доцент кафедри електроніки, робототехніки, автоматики та мехатроніки, Чернігівський національний технологічний університет (вул. Шевченка 95, м. Чернігів, 14035, Україна).

Voytenko Volodymyr - PhD in Technical Sciences, Associate Professor of the Electronics, Automation, Robotics and Mechatronics Department, Chernihiv National University of Technology (95 Shevchenko Str., 14035 Chernihiv, Ukraine).

E-mail: volodymyr.voytenko@inel.stu.cn.ua

ORCID: http://orcid.org/0000-0003-1490-0600

ResearcherID: F-8698-2014

Scopus Author ID: 36167678700

Сршов Роман Дмитрович - старший викладач кафедри електроніки, робототехніки, автоматики та мехатроніки,, Чернігівський національний технологічний університет (вул. Шевченка, 95, м. Чернігів, 14035, Україна).

Yershov Roman - senior lecturer of the Electronics, Automation, Robotics and Mechatronics Department, Chernihiv National University of Technology (95 Shevchenka str., 14035 Chernihiv, Ukraine).

E-mail: roman.d.yershov@gmail.com

ORCID: https://orcid.org/0000-0002-0267-2906

ResearcherID: H-1432-2016

Scopus Author ID: 57188719994

Войтенко В., Сршов Р. Моделі елементів системи електроприводів квадрокоптерів та автономних роботів. Технічні науки та технологї̈. 2019. № 3 (17). С. 175-187. 